\title{
Promoting a Just Education: Dilemmas of rights, freedom and justice
}

\author{
SHARON TODD \\ Stockholm Institute of Education
}

\begin{abstract}
This paper identifies and addresses some dilemmas to be faced in promoting educational projects concerned with human rights. Part of the difficulty that human rights education initiatives must cope with is the way in which value has been historically conferred upon particular notions such as freedom and justice. I argue here that a just education must grapple head-on with the conceptual dilemmas that have been inherited and refuse to shy away from the implications of those dilemmas. To do this I address the fundamental fictions upon which rights are based and view those fictions as nonetheless useful for opening up the ethical terms of human rights education. With reference to the work of Arendt, Lyotard and Levinas, I conclude that the real potential of human rights education lies in its capacity to provoke insights that help youth live with ambiguity and dilemma, where freedom, justice, and responsibility cannot be dictated to them, but rather involve tough decisions that must be made in everyday life.
\end{abstract}

Keywords: Arendt, ethics, freedom, human rights, justice, Lyotard, Levinas, responsibility, language game

Hannah Arendt (1965a), in her essay, 'The Crisis in Education', points to the power granted, however misguidedly, to education in political projects. She writes, 'The role played by education in all political utopias from ancient times onward shows how natural it seems to start a new world with those who are by birth and nature new' (p. 176). ${ }^{1}$ Indeed, this observation has become a sort of truism in how we think about education with respect to human rights in particular, admitting, it would seem, that the culture of rights needs education for its future security. The idea is that through institutionalised practices of knowledge, children will come to form habits of thought, attitude and spirit which are conducive to promoting and creating landscapes of living with others that embrace a commitment to democratic and rights-based principles. There is a large dose of commonsense-and indeed consensus, at least in the West-in this hope we grant to education, and in this trust we place in youth to be able to make a 'new world', better than the old one we were born into. And not simply better, but more just. In the West, human rights education initiatives have been developed in an attempt to ensure that youth can 
well take on the demands of democratic citizenship, both locally and globally. Such initiatives would therefore appear to be excellent starting points for the pursuit of justice, understood in terms of creating forms of living that serve to nourish the very freedoms that allow dignity in human life.

Thus it is with some discomfort that I approach writing about the dilemmas of human rights education, for it does indeed appear to be a luxury to write of dilemmas in times of such global want. Nonetheless, I address in this paper the fundamental fictions that rights are based on and how those fictions are useful for opening up the ethical terms of human rights education. Part of the difficulty that human rights education initiatives must cope with is the way in which value has been historically conferred upon particular notions such as freedom and justice. A just education, it seems to me, must grapple head-on with the conceptual dilemmas that have been inherited, especially with respect to freedom, and refuse to shy away from the implications of these dilemmas. If the UN Declaration is to be treated with the respect it deserves, it must be engaged as a living document that has the capacity under the weight of its own convictions to demand something more of us than simply learning about it. Rather, the questions addressed in this paper are: how might we bring into focus those underlying conceptions of freedom, justice and responsibility in ways that enhance our living arrangements and that do not leave us totally subject to an authoritarian reading of the declaration? How might we think beyond an education that merely seeks to inculcate knowledge, toward a just education that provokes insight into the conditions of freedom, justice and responsibility themselves?

I have intimated above that education is perceived to be instrumental to the purpose of human rights, yet the issue at stake is how might education contribute something more than mere transmission in enhancing the cause of justice through human rights? For it is difficult to escape the question of the difficulties of education itself in this context. It is not that education has no role to play (in fact I think it has a very important role) in familiarising students with basic rights, but even the best intentions of teachers and technologies of education cannot guarantee the expected outcomes, particularly one so grand as justice. Indeed I think it is wise to heed the observations of Jean-François Lyotard (1998) who considers that the very humanity of young persons reveals to adults (who are supposedly in the know') precisely what we lack:

Shorn of speech, incapable of standing upright, hesitating over the objects of its interest, not able to calculate its advantages, not sensitive to common reason, the child is eminently human because its distress heralds and promises things possible. Its initial delay in humanity, which makes it the hostage of the adult community, is also what manifests to this community the lack of humanity it is suffering from, and which calls on it to be more human. (pp. 3-4)

Responding to this call to be more human means that both human rights and education need to come together in ways that assume responsibility for children, which cannot be done solely through the content of what we adults teach. Part of 
a rethinking of human rights education, in my view, needs to take into account that the freedom, for instance, upon which it is based is not simply 'content', a concept to be apprehended, used, and ultimately applied to daily life. It seems to me that knowledge about rights is the bare minimum required and that the real potential of education lies in its capacities to provoke insights that help youth live well with ambiguity and dilemma, where freedom, justice, and responsibility cannot be dictated to them, but involve tough decisions that must be made in everyday life.

\section{Freedom in Rights: Fiction and Action}

Article 1 in the UN Declaration states: 'All human beings are born free and equal in dignity and rights'. Add to this Rousseau's (1762/1974) comment, that 'man is born free and everywhere is in chains' and what floats inevitably to the surface is the tension created when one mobilises the idea of 'natural' freedom to counteract the actual bonds of servitude humans continue to endure around the world. Thus freedom here is a fiction, a device we use to measure the very existence of people in chains as unjust. It is an ideal, not a description, which has little basis in the actuality of most people's lives. But, as Agnes Heller (1992) writes, 'statements such as "all men are born free" need not be unmasked as fictions, because they are meant to be fictions (or metaphors). Their ontological character is illusory. They are ethical and political principles. they [sic] are not theoretical, but rather pure practical principles' (p. 351). Thus the question of what to do with the fiction, in practice, is of utmost importance. For it is not to say that freedom has no meaning, if rights, and the freedom that is asserted in them, 'means to claim something that is due, which is justice' (ibid., p. 354).

Freedom here is needed for practical reasons, in order to take action, to leap into lively human activity and to decide what is just. But it is a freedom not based on the volition of an individual to direct itself to take action. Rather, as Arendt (1965b) claims, freedom is something that can only be experienced in practice. It is thus not an 'absolute' freedom, but is conditional upon a social reality. It is a concept, though, that has been corrupted in modernity by its turn inward, as though freedom were a phenomenon of the will, an expression of an inner life (ibid., p. 151).

Arendt instead proposes a double movement: that freedom can only emerge through political organization, and that freedom is the very reason why we have need of politics in the first place (Arendt, 1965b, p. 146). "Without a politically guaranteed public realm, freedom lacks the worldly space to make its appearance. To be sure it may still dwell in men's hearts as desire or will or hope or yearning; but the human heart, as we all know, is a very dark place, and whatever goes on in its obscurity can hardly be called a demonstrable fact' (ibid., p. 149). For Arendt, simply claiming that freedom belongs to the will puts us in a very precarious position indeed. What she stresses instead is that freedom emerges out of the communication we participate in with one another, as opposed to acting out of wilfulness. She writes that 'a state, moreover, in which there is no communication between the citizens and where each man thinks only his own thoughts is by 
definition a tyranny' (ibid., p. 164). The capacity, then, for freedom to be realized lies in a reorientation to freedom that demands constant political vigilance. It is upon the scales of public life that freedom's possibilities are weighed. Freedom as a practice, then, must always live in the shadow of its opposite; the threat to freedom comes not from a failure to exert one's will, but from certain arrangements of public life that threaten to dissolve its possibility.

As to the declaration that 'all men are born free', Arendt's views underline the nature of a necessary fiction, for if freedom is to mean anything at all it must participate in a practical realm, where social and political organization allow not for its expression, as if it existed prior to action, but for its inception. What Arendt captures is the interdependent nature of freedom; a freedom built on intersubjectivity, on communication, on public life.

Working within the dilemmas of freedom (as both fiction and practice) demands, then, attending vigilantly to the possibilities that the fiction of freedom grants us. With respect to education, it seems especially pertinent, then, to read the connection between freedom and rights less in terms of having a definitive content, and more in terms of how freedom performs in acting with others. Freedom is not about telling others how they should live, but engaging in a communicative process that focuses attention on the many faces of freedom within rights-based societies. Thus when Heller (1992) suggests, 'rights are the institutionalized forms of the concretization of universal values (both the value of freedom and of life)' (p. 93) she seems to sidestep the question as to how rights themselves and the freedom they represent are possibly contestable in the actual concrete communicative practices in which humans engage. While the fiction of freedom in the statement 'all human beings are born free' allows us to entertain, and helps to regulate, justice, the idea that all have a right to life as well as liberty leads to the very difficult work of building a new public realm while simultaneously aiming to secure individual needs. The question for human rights education is how might it exist in the space between creating environments of succour and nourishment of human life while creating possibilities for the active, practical condition of freedom.

\section{Just Responsibility}

In wanting to extend the importance Arendt places on the public, communicative quality of freedom, I also want to introduce here, through the work of Lyotard and Levinas, the idea that justice and responsibility are based neither on criteria nor content, and that this shifts our model of human rights education from one that is deducible from principles to one that emphasizes communicative practice. In my reading below, I draw out how this latter model is linked to a particular ethical conception of rights.

Seeing modernity as that which 'comprises in itself an impulsion to exceed itself into a state other than itself' (Lyotard, 1998, p. 25), Lyotard worries that pluralities that mark life in modernity impel us to reflect upon the universality of principles, like freedom and justice, which frequently have been used as means of oppression. Lyotard discusses justice through an analysis of language games and the ways 
certain statements perform certain functions. As we have already seen, the statement that 'humans are born free' is not a descriptive statement, even though it is stated as fact. Instead, it poses as a descriptive phrase that implores one to act as though each human being were indeed free. Conceived as a fiction for Heller, Lyotard posits freedom as the Idea that regulates justice (Lyotard \& Thébaud, 1985 , p. 84). Relying heavily on Kant, he proposes that freedom is not determinate; that is, it does not establish the content of laws, nor can it determine its own content (ibid.). 'Freedom is regulatory; it appears in the statement of the law only as that which must be respected; but one must always reflect in order to know if in repaying a loan or in refusing to give away a friend, etc., one is actually acting, in every single instance, in such a way as to maintain the Idea of a society of free beings' (ibid., pp. 84-5). Under this view, freedom cannot tell us how to judge, how to decide; it cannot be concretised, for it is an Idea that one uses reflectively, as opposed to obeying it as though it held the answers for combating injustice.

Now this carries significant meaning for justice. Freedom (even in the guise of a descriptive statement) cannot determine for us how we are to judge, or why we ought to judge. Descriptive statements cannot logically give rise to prescriptive ones (ibid., pp. 21-22). Thus, the statement that there is massive suffering in the world, while speaking a truth, does not logically lead to the statement that I ought to do something about it, which speaks a command to be just. 'In other words, in so far as justice is prescriptive it cannot be derived from theorizing "the true", (Smart, 1998, p. 52). There is no justification possible for being just, or for the command to be just; 'it is proper to prescription to be left hanging in midair' (Lyotard and Thébaud, 1985, p. 45). A prescriptive phrase does not denote or describe the human condition as it actually is, nor does it derive its ethical force from a factual depiction of the world. As prescription, it exists beyond the boundaries of what we can see, what we can know, what we can report. But it is far from 'empty'. For Lyotard, a judge decides, case-by-case, without definitive criteria. Justice comes about through the exercise of prudence, not the application of rigid criteria (ibid., 26). It is an idea of justice that guides the judge in her decision, and moreover, this idea is in turn regulated by, if you will, an imaginative faculty that seeks to bring the law in line with the individual circumstances of each case. In short, similar to Arendt in this respect (and perhaps in this respect alone), Lyotard asserts that judgement occurs in action.

The language game, then, of justice is one of prescription, and has no basis in fact or truth. Justice problematically rests within a language game that can have no grounding on the concrete content of freedom. Rather, it is situated within a set of, what Lyotard refers to as, 'pragmatics'; there are certain pragmatic rules that define each language game, and each of us participates in several (ibid., p. 93). The pragmatic of justice lies, for him, in the obligation we have to others to decide and to make that decision among competing language games. Most importantly, this pragmatics forces us to continually hold open the question of justice itself, where we can return to it again and again. That is, each time I come into contact with a situation, where individuals speak to me, they not only speak to me through different language games, but also command from me an obligation by virtue of the 
fact that they address me. They require a response. And that response can only live up to its name of response when I refuse to impose upon them a set of criteria or to hear their words only through a filter of laws, regulations, and such. Instead, the response that is commanded is a listening to the other knowing that my judgement must come through a reflexivity in which I continually ask myself-is this a just decision? This is the language game of justice. And although we can never know with complete certainty whether we have been just, Lyotard states that:

Absolute injustice would occur if the pragmatics of obligation, that is, the possibility of continuing to play the game of the just, were excluded. That is what is unjust. Not the opposite of the just, but that which prohibits that the question of the just and the unjust be, and remain, raised. Thus, obviously, all terror, annihilation, massacre, etc. or their threat, are, by definition, unjust. (ibid., pp. 66-7)

We can see that Lyotard is concerned to get away from the relativism that appears to be implied in any language game. But what is to be underscored here is that it is not 'anything goes', but that justice is held together both through obligation to the other and the Kantian idea of a society of reasonable, free beings. This latter idea, he is emphatic to point out, does not in any way determine our action. Indeed, if it were to do so, it would constitute a terror (ibid., p. 92), and make it impossible to keep open the question of justice. Instead, the idea guides our decisions in the context of the obligation that itself knows no language game, that rises up in our encounter with difference.

Obligation to others, in conjunction with the regulatory ideas of freedom and justice, inform the pragmatics of justice. As a practice, justice then does not rest on how well laws, or rights, are articulated, but on how individuals are responded to, which requires not treating those laws as though the contents of them were transparent. ${ }^{2}$ Thus in seeking to promote the right to freedom among women in Afghanistan or Guatemala or Ireland or France, such a right cannot be judged in the abstract-as if justice had little to do with the differences that matter to these women's life situations; it is not that there is a plurality of justices, but that there is a justice of plurality. ${ }^{3}$ It is only sensitivity and flexibility that keeps the self-questioning - am I being just? - at the forefront of one's decision. Justice, then, is to be seen 'against the horizon of a multiplicity or diversity' (ibid., p. 87). Interestingly, Lyotard attributes this refusal to see judgement simply through the means of obeying predefined prescriptives to the teachings of Judaism. 'The refinement that Judaism brings to the notion of obligation is precisely that one has to watch out for prescriptions that appear to be just or authorized; they are not always to be taken literally, and they may result in the most extreme injustice. They must always be taken as much as traps as obligatory prescriptions. And thus they always refer one back to responsibility, to the responsibility of listening, of lending oneself to obligation' (ibid., p. 66).

In this way, then, justice carries within its practice notions of responsibility and obligation. Levinas, upon whom Lyotard also draws, proposes that this obligation, which amounts to a command from the other, cannot be justified. Rather I am 
subject to the other as soon as she addresses me for no logical reason; I am commanded by her to respond beyond all reason. Thus, my commitment to her does not arise from the freedom of my will-i.e., that I choose to be responsible; it is instead a 'responsibility that is justified by no prior commitment' (Levinas, 1998a, p. 102). This non-justifiable responsibility is something that grips me unawares; just by encountering another's face an obligation to that other wells up in me. 'There is a paradox in responsibility, in that I am obliged without this obligation having begun in me, as though an order slipped into my consciousness like a thief, smuggled itself in ...' (ibid., p. 13). This paradox is precisely what underlies our commitments to justice - and to rights. My capacity to decide, to make decisions that keep open the question of justice, is, therefore, not a result of exercising my freedom. Quite the contrary. They lie instead in my capacity to be the receptacle for smuggled goods. 'The responsibility for the other can not have begun in my commitment, in my decision. The unlimited responsibility in which I find myself comes from the hither side of my freedom, from a "prior to every memory", an "ulterior to every accomplishment", from the non-present par excellence, the nonoriginal, the anarchical, prior to or beyond essence' (ibid., p. 10). As that which cannot be concretised (that is, that freedom exists in a particular condition), freedom can only be experienced as I exceed myself, take the other's command into me, and thereby enable the freedom of the other to emerge.

In terms of justice, I decide, evaluate, compare, and prioritise on the basis of my obligations to others, not upon the basis of pre-defined principles, laws, or rights. And, of course, the practice of justice then requires that I live in concert with those others. 'The one respected is not the one to whom, but the one with whom one renders justice. Respect is a relationship between equals. Justice presupposes this original equality' (Levinas, 1998b, pp. 43-44). Naturally, justice requires something more than simply my own judgement. And Levinas is adamant, of course, as a Jewish philosopher writing in the wake of the Holocaust, that we are able to judge that which is unjust; but nowhere does he describe the content of what that justice looks like. Thus, to judge totalitarian states, such as Nazi Germany, rests precisely on what Lyotard refers to as subjecting ourselves to a prescriptive. We exercise rational thought only after the command from the other has been heeded, and that command rests on our capacity to be moved by others' suffering, to allow it to enter us as difference. Thus it is not suffering in and of itself that gives us the reason to act, but our sensitivity to the plight of others initiates a command to respond responsibly.

Recognizing that justice simply does not lie within the judgements you and I make, but within forms of sociality that bring to mind Arendt's public sphere, Levinas reveals a necessary paradox: that the state is necessary for justice at the same time that it cannot enact a responsibility for each individual in its care. 'But it is very important, in my view, that justice should flow from, issue from, the pre-eminence of the other. The institutions that justice requires must be subject to the oversight of the charity from which justice issued. Justice, inseparable from institutions, and hence from politics, risks preventing the face of the other man from being recognized' (Levinas, 1999a, p. 176). In this sense, laws, rights, or 
institutions such as education, must continually keep vigilance over the inevitable and necessary failure of justice to be realised. Embedded within this is a plea for laws to change constantly in order to improve upon the possibilities for justice, or as we might say along with Lyotard, upon the pragmatics of the justice language game.

What I have discussed thus far has enormous bearing upon how rights might be rethought. In an essay entitled 'The Rights of Man and the Rights of the Other', Levinas proposes that rights begin with the Other, rather than with freedom (Levinas, 1987, p. 124). Justice can indeed come to the defence of rights, but if, and only if, it is not based on a notion of an autonomous freedom, or free will. $\mathrm{He}$ writes, 'in defending the rights of man, the latter should no longer be considered exclusively from the point of view of a conception of freedom that would already be the potential negation of every other freedom and in which, among freedoms, the just arrangement could only come from reciprocal limitation' (ibid., p. 123). A just arrangement in defence of rights suggests itself when freedom becomes linked to responsibility. 'One's duty regarding the other who makes appeal to one's responsibility is an investing of one's own freedom. ... My freedom and my rights, before manifesting themselves in my opposition to the freedom and rights of the other person, will manifest themselves precisely in the form of responsibility, in human fraternity' (ibid., p. 125). In another essay on the same topic, Levinas writes that while the universal character of freedom needs to be granted in defending rights, he also concedes that even this 'free limitation of its freedom ... in consenting to the rationality of the universal [i.e., that all humans are free]' does not guarantee that any good will result (Levinas, 1999b, p. 148). 'Unless a pre-eminent excellence were granted to the other out of goodness: unless good will were will, not just out of respect for the universality of a maxim of action, but out of the feeling of goodness. A simple feeling that we speak to children about, but that can have less innocent names, such as mercy or charity or love. An attachment to the other in his alterity to the point of granting him a priority over oneself' (ibid., p. 149).

The turn that Levinas makes is to view human rights as an ethical project, not a project of rationality or knowledge alone. Like Lyotard, such a project cannot be grounded in rational arguments; it is rather a practise constructed around a recognition both of the idea of freedom and that of justice, based on a command to respond to the other. This command, moreover, is something prescribed to me before any freedom. Freedom, then, is not the ground of rights; rather responsibility is.

\section{Human Rights Education: Toward Responsibility and Justice?}

Documents and policies dealing with human rights education place great emphasis on how best to instil and inculcate among children the values inherent in the UN Declaration as well as various Human Rights Codes. ${ }^{4}$ The calls for education to transmit the contents of the Declaration and to help students engage in an understanding of human rights that are found within the UN documents themselves, smoothes over the very dilemmas that students face in coming to grips with how abstract and apparently universal principles speak to the particularities of their own 
life situations. And this is especially true when those students come from societies, cultures, and languages, where freedom and individuality signify something quite different than they suggest in the schools in which they are being educated. Moreover, there is no single content that one can give to freedom across languages. For instance, the French term 'liberté' and the English 'freedom' do not encompass the same nuances of meaning. ${ }^{5}$ Furthermore, calls for individual freedom cannot be easily imported into cultures with a deep sense of duty to community. ${ }^{6}$ Moreover, if pursuing justice, which is the stated aim of the development of the UN Declaration in the first place, cannot be secured through recourse to knowledge alone, then it would seem that the goal of disseminating knowledge as fixed and transportable to practise is simply not adequate. What I am offering here, by way of conclusion, are points that suggest possibilities for rethinking education's role in the project of human rights by working with, as opposed to smoothing over, the dilemmas of freedom and justice.

First, following the above thinkers, but particularly Arendt, education can be deeply involved in constructing public spaces for students to experience human rights. With respect to the right to education (Article 26 of the UN Declaration), UN Special Rapporteur Katarina Tomaševski (2001) proposes that all aspects of education integrate human rights, as opposed to treating human rights as a separate topic in social studies. In particular, she is concerned with focusing on the process of education itself. With respect to process, I earlier raised a question: how might education participate in creating spaces that nourish human life as it creates possibilities for the active, practical condition of freedom? If public life is to be invigorated, then how might any systemic practice, including education, attend to the needs of individuals? There are no clear, prescriptive answers to these questions. Listing a series of tasks that would bring about such attentiveness would work precisely against the judgement that teachers and students themselves need to exercise in making decisions about their school communities. Yet, it is not enough to say nothing. Understanding first of all that pedagogies, even when promoting conditions for social justice, cannot rely on curriculum alone to create an atmosphere of equality and respect is a step in the right direction. The authority granted to teachers suggests that they need to create conditions where students begin to exercise their faculties of communication in order to produce lively social and intellectual communities. Differential treatment of individuals can indeed be an important place to begin, but seen in the service of enabling students to live also with the difficulties of pluralism; to have opportunities to listen to one another and to speak with responsibility is certainly something that any human rights education can be concerned with, not just in terms of the classroom, but in terms of community organizations with which schools are connected.

Secondly, the difficulties posed by freedom and justice (both of which remain on a horizon of possibility, as opposed to something one achieves through certain behaviour), demands a rethinking of education's role in promoting human rights. Even in familiarising students with the actual articles of the Declaration, or using case studies to encourage them to apply certain rights and codes in order to make judgements, the tasks are set up too often to reflect the ease with which judgement 
can be made. It seems to me we do a disservice to children to present judgement in this light. Although we are not educating children to be Human Rights Commission judges, we are educating them to participate in society (of which school is undoubtedly a part) reflectively and critically. How students make meaning of human rights, how they fathom freedom and justice, and how they perceive their own rights in relation to others can be given expression through engaging with the dilemmas of rights and judgements as opposed to pretending they do not exist. To have students be creative with language (or perhaps even a language game) that allows them some space for indeterminacy, allows them to ask questions and ponder the very dilemmas that rights present to individuals and states, and does not denigrate the project of human rights. I think some human rights educators are afraid that once uncertainty is allowed in, rights will be thrown out the window and an anything-goes attitude will run rampant. Although I acknowledge this as a real concern, I do think that discussions with youth on how critique might be constructed on the basis of an affirmation of rights can be crucial. Further, the educational documentation that exists often proposes teaching about rights through violations, with no adequate language for teachers (and students themselves) to think about the strong expressions of guilt, powerlessness, and apathy that often accompany the reception of these stories. Thus, an important task for human rights education is to begin to construct a language that allows youth to question their responses in ways that make obvious their own implication in the lives of others.

Finally, a note on responsibility. If freedom is found in responsibility, one might be tempted to state that the role of education in human rights initiatives is to educate responsibility in students. But my discussion of Levinas suggests that the obligation we have toward others is not something one learns as a piece of knowledge. Responsibility is a response to the command of the other; it is a prescriptive to a prescriptive. In no way can responsibility be instilled or inculcated in a direct fashion and thus it cannot be systemised into any curricula or teacher manual. But this is not to say that it has no bearing upon education. In fact, viewing rights in terms of responsibility rather than entitlement (the latter making up much of the educational literature), suggests a reorientation to the actual teaching of human rights. Moving away from didactic materials that seek only to ensure students have learned what their rights are, a renewed education would need to discover ways of creating a pedagogy of implication. That is, a pedagogy whereby we are continually vigilant in attending to the needs of others in a way that takes responsibility for our own responses. Such vigilance does not come easily, but if human rights education is to have any hope of creating a just education, paying attention to how we judge and why we judge seems to demand just such measures.

\section{Acknowledgements}

I would like to thank the Social Sciences and Humanities Research Council of Canada whose financial support made the writing of this paper possible. This paper is based on a study conducted on human rights education literature, with a particular focus on documentation from Canada and Sweden. 


\section{Notes}

1. Arendt is, of course, critical of this view; but it is the seeming naturalness of the link between education and political projects that continue to be operative, in my mind, to human rights education initiatives.

2. Lyotard is emphatic that 'any attempt to state the law, for example, to place oneself in the position of the enunciator of the universal prescription is obviously infatuation itself and absolute injustice, in point of fact' (Lyotard \& Thébaud, 1985, p. 99). The problem with Human Rights declarations is that of course they have attempted to state the law, and thus to a large degree Lyotard sees them as closing off possibilities for justice. See also his comments in Lyotard (1988, section 44, p. 31; 1998, pp. 5-6).

3. Lyotard asks: 'Can there be a plurality of justices? Or is the idea of justice the idea of a plurality? That is not the same question. I truly believe that the question we face now is that of a plurality, the idea of a justice that would at the same time be that of a plurality, and it would be a plurality of language games' (Lyotard and Thébaud, 1985, p. 95).

4. As stated above, this theoretical paper has grown out of a study conducted on Human Rights Education literature and documentation, particularly that found in Canada and Sweden.

5. One can also see even greater difficulties when looking at translations. For instance, the beginning of Article 4 of the Rights of Man reads: 'La liberté consiste à pouvoir faire tout ce que ne nuit pas à autrui ...'. In English, liberté is, as usual, translated as liberty, while pouvoir faire, which means, literally, power to make, is translated as freedom.

6. See, in particular, Wang (2002) and Pollis \& Schwab (1979).

\section{References}

Arendt, H. (1965a) The Crisis in Education, in: Between Past and Future (New York, Meridian Books).

Arendt, H. (1965b) The Crisis of Freedom, in: Between Past and Future (New York, Meridian Books).

Heller, A. (1992) Rights, Modernity and Democracy, in: D. Cornell, M. Rosenfeld, and D. G. Carlson (eds), Deconstruction and the Possibility of Fustice (New York, Routledge).

Levinas, E. (1987) The Rights of Man and the Rights of the Other, in: Outside the Subject, M. B. Smith, trans. (Stanford, CA, Stanford University Press).

Levinas, E. (1998a) Otherwise Than Being or Beyond Essence, A. Lingis, trans. (Pittsburgh, PA, Duquesne University Press).

Levinas, E. (1998b) The Ego and the Totality, in: Collected Philosophical Papers, A. Lingis, trans. (Pittsburgh, PA, Duquesne University Press).

Levinas, E. (1999a) Violence of the Face, in: Alterity and Transcendence, M. B. Smith, trans. (New York, Columbia University Press).

Levinas, E. (1999b) The Rights of the Other Man, in: Alterity and Transcendence, M. B. Smith, trans. (New York, Columbia University Press).

Lyotard, J-F. (1988) The Differend (Minneapolis, MN, University of Minnesota Press).

Lyotard, J-F. (1998) The Inhuman: Reflections on Time, G. Bennington and R. Bowlby, trans. (Cambridge, Polity Press).

Lyotard, J-F. \& Thébaud, J-L. (1985) fust Gaming, W. Godzich, trans. (Minneapolis, University of Minnesota Press).

Pollis, A. \& Schwab, P. (1979) Introduction, in: Human Rights: Cultural and Ideological Perspectives (New York, Praeger).

Rousseau, J-J. (1762/1974) The Social Contract, C. Sherover, trans. (New York, New American Library). 
Smart, B. (1998) The Politics of Difference and the Problem of Justice, in: C. Rojek and B. S. Turner (eds), The Politics of Fean-François Lyotard: Fustice and Political Theory (London, Routledge).

Tomaševski, K. (2001) Human Rights in Education as a Prerequisite for Human Rights Education (Stockholm, Swedish International Development Agency).

Wang, Z. (2002) Toward a Postmodern Notion of Human Rights, Educational Philosophy and Theory, 34:2. 